\title{
PENGGUNAAN PARADIGMA GAYA GESEK SEBAGAI GAYA REAKSI UNTUK MEREDUKSI MISKONSEPSI MAHASISWA CALON GURU FISIKA
}

\author{
Ahmad Busyairi*, Joni Rokmat, Ni Nyoman Sri Putu Verawati \\ Program Studi Pendidikan Fisika, FKIP Universitas Mataram \\ *Corresponding Author: ahmad.busyairi@unram.ac.id
}

\section{Article History}

Received : April 10 $0^{\text {th }}, 2021$

Revised : April 15 $15^{\text {th }}, 2021$

Accepted : May $05^{\text {th }}, 2021$

Published : May 09 $9^{\text {th }}, 2021$

\begin{abstract}
Salah satu masalah yang sering dijumpai dalam dunia pendidikan khusunya pada mata pelajaran fisika adalah adanya miskonsepsi pada siswa atau mahasiswa. Penelitian ini bertujuan untuk menguji sejauh mana efektivitas penggunaan paradigma gaya gesek sebagai gaya reaksi dalam mereduksi miskonsepsi mahasiswa calon guru fisika. Metode yang digunakan adalah penelitian kuantitatif dengan desain one group pretest-posttest. Sampel terdiri dari 27 mahasiswa calon guru fisika di salah satu universitas yang ada di kota Mataram. Instrumen yang digunakan dalam penelitian berupa tes tiga tingkat. Sebanyak 10 item soal dengan 30 buah pertanyaan digunakan dalam penelitian ini. Tes dilakukan sebanyak dua kali yaitu sebelum dan setelah perlakuan. Data hasil tes kemudian dianalisis dengan menggunakan statistik deskriptif untuk mengetahui persentase jumlah mahasiswa yang paham konsep, miskonsepsi, atau tidak paham konsep. Hasil analisis data menunjukkan bahwa terdapat peningkatan presentase jumlah mahasiswa yang paham konsep yang diikuti dengan berkurangnya mahasiswa yang mengalami miskonsepsi dan tidak paham konsep khususnya dalam menentukan jenis, arah, dan besar gaya gesek yang bekerja pada suatu benda. Dengan demikian dapat disimpulkan bahwa penggunaan paradigma gaya gesek sebagai gaya reaksi dapan digunakan sebagai alternatif pembelajaran untuk meningkatkan pemahaman konsep dan mereduksi miskonsepsi mahasisw khususnya pada materi gaya gesek.
\end{abstract}

Keywords: Gaya gesek, gaya reaksi, miskonsepsi, calon guru fisika.

\section{PENDAHULUAN}

Fisika merupakan salah satu cabang Ilmu Pengetahuan Alam yang mempelajari berbagai fenomena alam beserta penyebabnya. Fenomena alam ini dituangkan dalam bentuk konsep, teori, dan hukum sehingga dapat diterima dengan mudah oleh pikiran manusia (Kaniawati, 2017). Melalui konsep, seseorang dapat menyederhanakan pemikirannya dengan menggunakan satu istilah untuk menjelaskan fenomena yang terjadi di alam semesta. Istilah tersebut digunakan untuk mewakili realitas yang kompleks. Misalnya, fenomena perpindahan energi dari benda yang bersuhu tinggi ke benda yang bersuhu lebih rendah dituangkan dalam konsep kalor sedangkan besarnya perubahan posisi dari suatu benda tiap satuan waktu dikenal dengan konsep kelajuan.

Gambaran atau pemahaman seseorang terhadap suatu konsep tertentu disebut dengan konsepsi (Suparno, 2005). Pada kenyataanya, konsepsi setiap orang terhadap sutu konsep tertentu dapat berbeda-beda. Oleh karena itu, di dalam kelas kita akan mengenal konsepsi ilmuan, konsepsi guru, konsepsi siswa dan sebagainya. Namun konsepsi ilmuan atau ahli dipandang sebagai konsepsi yang paling benar atau yang paling banyak diterima dan diakui (Hikmawati, \& Sutrio, 2019). Konsepsi yang tidak sesuai dengan konsepsi ilmuan secara umum disebut miskonsepsi. Miskonsepsi merupakan suatu istilah yang menunjukkan adanya perbedaan pemikiran antara konsep yang dimiliki siswa dengan konsep yang ditetapkan ahli (Solas \& Wilson, 2017; Samsudin et al., 2017; Fratiwi, et. al., 2017; Osman, et. al., 2017; McLaughlin \& MacFadden; 2014).

Memahami konsep dengan benar memiliki peranan yang sangat penting dalam keberhasilan pembelajaran fisika karena menjadi dasar dalam mempelajari fenomena yang terjadi di alam. Siswa yang memahami konsep dengan baik akan mampu mengabstraksi fenomena yang diamati sehingga fenomena tersebut dapat diklasifikasikan dalam golongan tertentu dengan tepat. Begitupun sebaliknya, siswa yang tidak memahami konsep dengan benar (miskonsepsi) akan mengklasifikasikan fenomena dengan tidak tepat yang pada akhirnya dapat menghambat 
tercapainya tingkatan kognitif yang lebih tinggi. Hal ini akan berpengaruh pada rendahnya hasil belajar kognitif siswa.

Namun, berdasarkan hasil studi pustaka memperlihatkan bahwa masih banyak siswa mengalami miskonsepsi. Hasil penelitian Kaniawati, et.al., (2019) memperlihatkan bahwa $66,0 \%$ siswa mengalami miskonsepsi pada konsep Hukum Newton. Sebanyak 39,9\% siswa mengalami miskonsepsi pada konsep listrik dinamis (Ismail, et.at., 2015). Pada materi cahaya, sebanyak 26,2\% siswa mengalami miskonsepsi (Wahyuni, et.al., 2018). Begitu juga pada materi suhu dan kalor $12,9 \%$ siswa mengalami miskonsepsi (Lestari, et.al., 2015). Dari beberapa hasil penelitian tersebut memperlihatkan bahwa, siswa mengalami miskonsepsi hampir di semua materi pada mata pelajaran fisika.

Secara umum miskonsepsi pada siswa dapat disebabkan oleh banyak faktor salah satunya adalah faktor guru yang mengajar di kelas (Barke, et.al., 2009). Kesalahan guru dalam mengajar, konsepsi guru yang salah, dan pemahan guru yang tidak memadai dapat menimbulkan miskonsepsi pada siswa. Miskonsepsi yang disebabkan oleh kesalahan guru biasanya agak sulit dibenahi karena siswa merasa yakin bahawa konsep yang diberikan guru sudah benar. Dengan demikian, sebelum mengajar sebaiknya guru atau calon guru harus benar-benar menguasai materi yang akan diajarkan di kelas.

Berdasarkan hasil studi pendahuluan pada mahasiswa calon guru Fisika di salah satu Universitas yang ada di kota Mataram memperlihatkan bahwa masih banyak mahasiswa calon guru Fisika yang mengalami miskonsespi. Pada materi gaya gesek misalnya, terdapat $52,67 \%$ mahasiswa mengalami miskonsepsi, $39,50 \%$ tidak paham konsep, dan hanya 7,83\% mahasiswa yang benar-benar memahami konsep. Hal ini menunjukkan bahwa metode atau strategi pembelajaran yang selama ini gunakan dosen masih belum optimal mereduksi miskonsepsi yang terjadi pada mahasiswa. Oleh karena itu, perlu ada alternatif pembelajaran untuk mengatasi permasalahan tersebut. Salah satu alternatif yang dapat digunakan untuk mereduksi miskonsepsi khususnya pada materi gaya gesek yaitu dengan menggunakan paradigma gaya gesek sebagai gaya reaksi.

Dengan menggunakan paradigma gaya gesek sebagai gaya reaksi diharapkan dapat lebih memudahkan mahasiswa dalam mengidentifikasi ada tidaknya, jenis, dan arah gaya gesek pada benda yang bergerak translasi dan atau rotasi. Sebagai contoh, untuk mengetahui ada tidaknya gaya gesek yang bekerja pada suatu benda cukup dengan melihat apakah pada benda tersebut terdapat gaya aksi atau tidak. Jika tidak terdapat gaya aksi yang diberikan oleh benda pertama ke benda kedua atau sebaliknya, maka dapat dipastikan tidak ada gaya gesek walaupun permukaan kedua benda tersebut kasar. Begitu juga untuk menentukan arah gaya gesek pada suatu benda cukup dengan melihat arah gaya aksi. Arah gaya gesek (gaya reaksi) berlawanan dengan arah gaya aksi tersebut

\section{METODE}

Metode yang digunakan adalah penelitian kuantitatif dengan desain one group pretestposttest (Frankel, et.al., 2012). Penelitian ini tidak menggunakan kelas pembanding namun sudah menggunakan pretest-posttest sehingga efektifitas penggunaan paradigma gaya gesek sebagai gaya reaksi dalam mereduksi miskonsepsi mahasiswa dapat diketahui dengan pasti.

Tabel 1. One Group Pretest-Posttest Design

\begin{tabular}{ccc}
\hline Pretest & Treatment & Posttest \\
\hline $\mathbf{0}_{\mathbf{1}}$ & $\begin{array}{c}\text { Model Project Based } \\
\text { Learning }(\mathrm{PjBL})\end{array}$ & $\mathrm{O}_{2}$ \\
\hline
\end{tabular}

\section{Keterangan:}

$\mathrm{O}_{1}=$ Skor miskonsepsi awal mahasiswa

$\mathrm{O}_{2}=$ Skor miskonsepsi akhir mahasiswa

Penelitian ini dilakukan di salah satu Universitas yang ada di kota Maratam, Nusa Tenggara Barat, Indonesia. Populasi dari penelitian ini adalah seluruh mahasiswa calon guru fisika tahun akademik 2019/2020 yang sedang menempuh matakuliah Fisika Dasar I yang berjumlah 59 Mahasiswa. Sampel terdiri dari 27 Mahasiswa. Pengambilan sampel menggunakan teknik simple random sampling. Teknik simple random sampling adalah teknik pengambilan sampel dari anggota populasi yang dilakukan secara acak tanpa memperhatikan strata yang ada dalam populasi (Sugiyono, 2012).

Instrumen yang digunakan dalam penelitian ini berupa tes tiga tingkat (three tier test). Sebanyak 10 item soal dengan 30 buah pertanyaan digunakan dalam penelitian ini. Sebelum digunakan, instrumen tes terlebih 
dahulu divalidasi oleh ahli. Validasi ini bertujuan untuk melihat kesesuaian antara isi instrumen dengan materi yang sudah diajarkan, kesesuaian soal dan jawaban, serta kesesuaian tata bahasa.

Tes dilakukan sebanyak dua kali yaitu sebelum dan setelah perlakuan. Data hasil tes kemudian dikategorikan dan dianalisis dengan menggunakan statistik deskriptif untuk mengetahui persentasi jumlah mahasiswa yang memahami konsep, miskonsepsi, atau tidak paham konsep. Berikut adalah pedomen pengkategorian konsepsi mahasiswa dengan menggunakan tes tiga tingkat (three tier test) (Arslan, Cigdemoglu, \& Moseley, 2012).

Tabel 2. Pedoman pengkategorian konsepsi mahasiswa dengan menggunakan instrument three tier test

\begin{tabular}{cccccccc}
\hline Jawaban & Kode & Alasan & Kode & Keyakinan & Kode & Kategori & Kode \\
\hline Benar & B & Benar & B & Yakin & Y & Paham Konsep & PK \\
Benar & B & Salah & S & Yakin & Y & Miskonsepsi & M \\
Salah & S & Benar & B & Yakin & Y & Miskonsepsi & M \\
Salah & S & Salah & S & Yakin & Y & Miskonsepsi & M \\
Benar & B & Benar & B & Tidak Yakin & TY & Menebak & TB \\
Benar & B & Salah & S & Tidak Yakin & TY & Tidak Paham Konsep & TPK \\
Salah & S & Benar & B & Tidak Yakin & TY & Tidak Paham Konsep & TPK \\
Salah & S & Salah & S & Tidak Yakin & TY & Tidak Paham Konsep & TPK \\
\hline
\end{tabular}

\section{HASIL DAN PEMBAHASAN}

\section{Hasil}

Persentase jumlah mahasiswa calon guru fisika yang paham konsep (PK), miskonsepsi (M), dan tidak paham konsep (TPK) berdasarkah hasil pretest dan posttest pada materi gaya gesek dapat diliha pada grafik berikut.

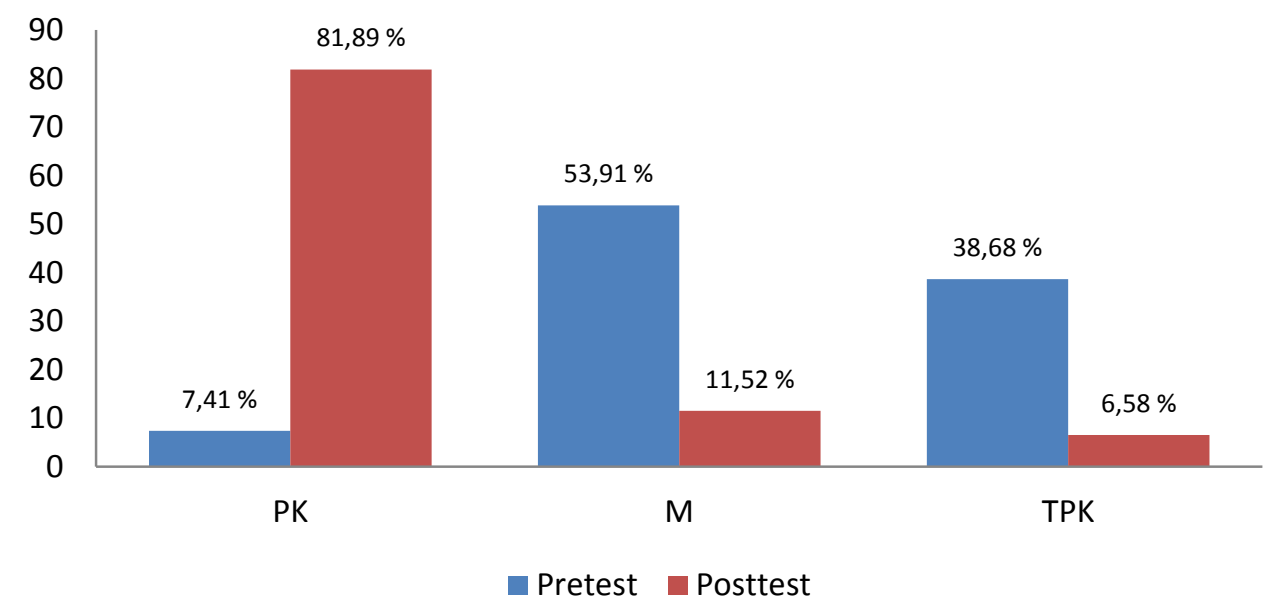

Grafik 1. Persentase jumlah mahasiswa yang paham konsep, miskonsepsi, dan tidak paham konsep

Hasil analisis data memperlihatkan bahwa persentase jumlah mahasiswa yang paham konsep mengalami peningkatan cukup besar sedangkan jumlah mahasiswa yang mengalami miskonsepsi dan tidak paham konsep rata-rata mengalami penurunan. Hal ini menunjukkan bahwa secara umum penggunaan paradigma gaya gesek sebagai gaya reaksi mampu meningkatkan pemahaman siswa dan mereduksi miskonsepi yang terjadi pada mahasiswa khususnya pada materi gaya gesek.

Selanjutnya, untuk keperluan analisis yang lebih mendalam akan diurakai persentase jumlah mahasiswa yang PK, M, dan TPK berdasarkan sub materi gaya gesek seperti yang ditunjukkan pada tabel berikut. 
Tabel. 3. Persentase jumlah mahasiswa yang PK, M, dan TPK berdasarkan sub materi gaya gesek

\begin{tabular}{ccccccc}
\hline \multirow{2}{*}{ Sub Materi } & \multicolumn{3}{c}{ Pretest (\%) } & \multicolumn{3}{c}{ Posttest (\%) } \\
\cline { 2 - 7 } & PK & M & TPK & PK & M & TPK \\
\hline Menentukan jenis gaya gesek & 14,81 & 70,37 & 14,81 & 79,63 & 11,11 & 9,26 \\
Menentukan arah gaya gesek & 3,70 & 56,48 & 39,81 & 76,85 & 13,89 & 9,26 \\
Menentukan besar gaya gesek & 7,41 & 39,51 & 53,09 & 90,12 & 8,64 & 1,23 \\
\hline
\end{tabular}

Hasil analisis data memperlihatkan bahwa jumlah mahasiswa yang paham konsep mengalami peningkatan yang cukup besar di semua sub materi gaya gesek sedangkan jumlah mahasiswa yang mengalami miskonsepsi dan tidak paham konsep rata-rata mengalami penurunan. Besarnya persentase peningkatan jumlah mahasiswa yang paham konsep dan penurunan jumlah mahasiswa yang mengalami miskonsepsi dan tidak paham konsep untuk tiaptiap sub materi gaya gesek dapat dilihat pada tabel berikut.

Tabel. 4. Persentase peningkatan/penurunan jumlah mahasiswa yang PK, M, dan TPK.

\begin{tabular}{|c|c|c|c|}
\hline \multirow{2}{*}{$\begin{array}{l}\text { Sub } \\
\text { Materi }\end{array}$} & \multicolumn{3}{|c|}{$\begin{array}{c}\text { Persentase peningkatan }(+) \text { atau } \\
\text { penurunan }(-) \text { jumlah mahasiswa yang }\end{array}$} \\
\hline & PK (\%) & $\mathrm{M}(\%)$ & TPK (\%) \\
\hline (1) & 64,82 & $-59,26$ & $-5,55$ \\
\hline (2) & 73,15 & $-42,59$ & $-30,55$ \\
\hline (3) & 82,71 & $-30,87$ & $-51,86$ \\
\hline
\end{tabular}

Keterangan Sub Materi: (1) menentukan jenis gaya gesek, (2) menentukan arah gaya gesek, dan (3) menentukan besar gaya gesek

\section{Pembahasan}

\section{Pola Miskonsepsi Mahasiswa}

Berdasarkan hasil pretest seperti yang ditunjukkan pada Grafik 1 di atas terlihat bahwa masih banyak mahasiswa yang mengalami miskonsepsi dan tidak paham konsep pada materi gaya gesek. Sebanyak 53,81\% mahasiswa yang mengalami miskonsepsi pada materi ini. Jumlah ini jauh lebih besar dari pada jumlah mahasiswa yang paham konsep yaitu hanya sebesar $7,41 \%$. Artinya, masih banyak mahasiswa yang salah dalam memahami konsep gaya gesek terutama dalam menentukan jenis, arah, dan besar gaya gesek yang bekerja pada suatu benda dalam berbagai keadaan.

Sebagai contoh, ketika mahasiswa diintruksikan untuk mengidentifikasi gaya gesek yang terjadi pada sebuah benda yang diam di atas lantai datar kasar seperti terlihat pada Gambar 1 berikut.

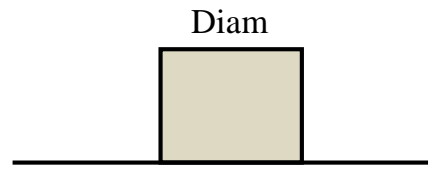

Gambar 2. Balok Diam di Atas Lantai Kasar

Sebanyak 62,96\% mahasiswa mengalami miskonsepsi dan sisanya sebanyak $37,04 \%$ tidak paham konsep. Mereka beranggapan bahwa gaya gesek yang bekerja pada benda diam adalah gaya gesekan statis yang besarnya dapat dihitung dengan persamaan $f_{s}=\mu_{s} N$. Hal ini menunjukkan bahwa di dalam struktur kognitif mahasiswa tertanam sebuah anggapan bahwa jika dua buah benda kasar saling bersentuhan maka pasti akan timbul gaya gesek pada permukaan benda yang bersentuhan. Namun ketika mereka diperintahkan untuk menunjukkan arah dari gaya gesek tersebut, mahasiswa mulai terlihat bingung dan tidak konsisten.

Selain itu, ketika mahasiswa diberi permasalahan untuk menentukan arah gaya gesek yang bekerja pada pada telapak kaki seekor kucing yang sedang berjalan dan roda belakang sepeda yang sedang berputar tanpa slip seperti yang ditunjukan pada gambar berikut.

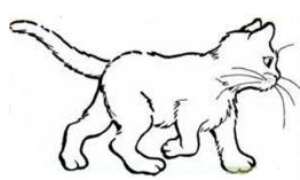

(a)

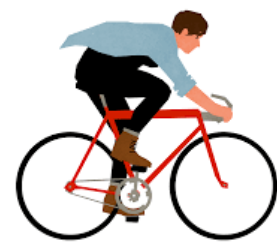

(b)
Gambar 3. (b) seekor kucing bergerak ke kanan, (b) seorang anak mengayuh sepeda ke kanan

Sebanyak 70,37\% mahasiswa beranggapan bahwa jenis gaya gesek yang bekerja pada peristiwa tersebut adalah gaya gesekan kinetis dengan alasan karena benda sedang dalam keadaan bergerak. Sebenyak 56,48\% mahasiswa salah dalam menentukan arah gaya gesek pada persistiwa tersebut. Mereka beranggapan bahwa 
arah gaya gesek selalu berlawanan dengan arah pergerakan benda.

Dari pola jawaban mahasiswa terlihat bahwa, mereka meninjau sistem benda secara utuh. Artinya ketika sistem benda yang ditinjau sedang dalam keadaan bergerak, maka secara otomatis gaya gesek yang bekerja pada benda tersebut adalah gaya gesekan kinetis. Begitu juga ketika sistem benda bergerak ke kanan, maka arah gaya gesek yang bekerja pada benda tersebut pasti ke kiri karena mereka beranggapan bahwa arah gaya gesek selalu berlawanan dengan arah gerak benda.

Dalam menentukan besar gaya gesek yang bekerja pada suatu benda, sebanya 39,51\% mahasiswa yang mengalami miskonsepsi dan 53,09\% mahasiswa tidak paham konsep. Hal ini terlihat katika mereka diberikan permasalahan untuk menentukan besarnya gaya gesek yang bekerja pada sebuah lemari yang didorong dengan gaya $\mathrm{F}$ hingga menyebabkan lemari bergerak dengan kecepatan konstan.

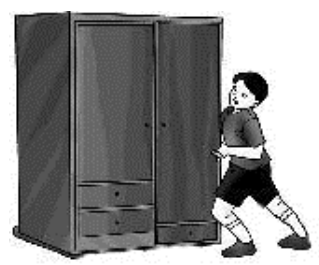

Gambar 4. Seorang anak mendorong lemari

Sebanyak $62,96 \%$ mahasiswa mengalami miskonsepsi pada kasus ini. Mereka beranggapan bahwa ketika sebuah benda didorong hingga benda tersebut bergerak menandakan bahwa besarnya gaya dorong yang diberikan pada benda tersebut lebih besar dari gaya gesek antara lemari dengan lantai. Begitupun sebaliknya, sebanyak 7,4\% mahasiswa beranggapan bahwa jika sebuah benda dirong namun benda tetap dalam keadaan diam, maka hal tersebut menandakan bahwa besarnya gaya dorong pada benda lebih kecil dari gaya gesek dari benda tersebut.

\section{Efektivitas Penggunaan Paradigma Gaya Gesek sebagai Gaya Reaksi}

Untuk mereduksi miskonsepsi pada mahasiswa, digunakan paradigma gaya gesek sebagai gaya reaksi. Dengan menggunakan paradigma ini, kita memandang bahwa gaya gesek merupakan sebuah gaya reaksi. Seperti yang kita ketahui bahwa, gaya reaksi hanya akan muncul jika ada gaya aksi. Oleh karena itu, untuk mengetahui ada tidaknya gaya gesek yang bekerja pada suatu benda cukup melihat apakah pada benda tersebut terdapat gaya aksi atau tidak. Jika tidak terdapat gaya aksi yang diberikan oleh benda pertama ke benda kedua atau sebaliknya seperti yang ditunjukkan pada Gambar 1 di atas, maka dapat dipastikan bahwa gaya gesek yang bekerja pada benda tersebut bernilai nol walaupun permukaan kedua benda tersebut kasar. Dengan menggunakan paradigma gaya gesek sebagai gaya reaksi, mahasiswa dapat lebih mudah menentukan ada tidaknya gesekan yang bekerja pada suatu benda yang sedang diam. Terdapat penurunan miskonsepsi sebesar 51,85\% persen pada kasus ini.

Penggunaan paradigma gaya gesek sebagai gaya reaksi juga efektif dalam menentukan jenis gesekan yang bekerja pada suatu benda. Hal ini terliat dari persentase jumlah mahasiswa yang mengalami miskonsepsi pada kasus ini mengalami penurunan sebesar 59,26\% dan jumlah mahasiswa yang paham konsep bertambah sebesar $64,82 \%$.

Untuk menentukan jenis gaya gesek yang bekerja pada suatu benda, kita dapat meninjau apakah benda teresbut begerak atau diam sesaat relatif terhadap benda yang bergesekan. Pada kasus di atas, jika kita tinjau interaksi telapak kaki kucing dengan lantai. Ketika telapak kaki kucing bersentuhan dengan lantai, telapak kaki kucing diam (tidak slip atau tergelincir) relatif terhadap lantai selama keduanya bersentuhan sehingga dapat ditentukan bahwa jenis gaya gesek yang bekerja pada telapak kaki kucing adalah gaya geseken statis. Dengan menggunakan metode yang sama, kita juga dapat menentukan bahwa jenis gaya gesek yang bekerja pada roda belakang sepeda adalah gaya gesekan statis karena permukaan roda belakang sepeda diam (tidak slip) relatif terhadap tanah sesaat ketika permukaan roda sepeda bersentuhan dengan tanah.

Selain itu, penggunaan paradigma gaya gesek sebagai gaya reaksi juga efektif untuk menentukan arah gaya gesek yang bekerja pada suatu benda. Untuk menentukan arah gaya gesek, cukup dengan melihat arah gaya aksi yang diberikan benda tersebut pada permukaan benda lainnya. Jika arah gaya aksi ke kanan maka tentu arah gaya reaksi atau gaya geseknya akan ke kiri. Pada kasus di atas, jika kita tinjau interaksi telapak kaki kucing dengan lantai. Ketika kucing akan bergerak ke depan, maka tentu kucing tersebut akan mendorong lantai dengan telapak kakinya ke arah belakang. Ini adalah gaya aksi yang diberikan benda (telapak kaki kucing) pada 
lantai sehingga lantai akan memberikan gaya reaksi pada telapak kaki kucing ke arah depan sehingga arah gaya gesek yang bekerja pada telapak kaki kucing adalah ke depan sama dengan arah gerak kucing.

Hal serupa terjadi pada roda belakang sepeda. Jika kita melihat interaksi antara roda belakang dengan lantai, ketika roda sepeda berputar searah putaran jarum jam terlihat bahwa permukaan roda belakang sepeda memberikan gaya dorong pada lantai yang arahnya ke belakang. Ini adalah gaya aksi yang diberikan permkaan roda belakang sepeda pada lantai sehingga lantai akan memberikan gaya reaksi (gaya gesek) ke arah sebaliknya. Hal inilah yang menyebabkan arah gaya gesek yang bekerja pada roda belakang sepeda adalah ke depan sama dengan arah gerak sepeda.

Dengan menggunakan paradigma gaya gesek sebagai gaya reaksi, dapat lebih memudahkan mahasiswa dalam menentukan arah gaya gesek yang bekerja pada suatu benda. Hal ini terliat dari persentase jumlah mahasiswa yang mengalami miskonsepsi pada kasus ini mengalami penurunan sebesar $42,59 \%$ dan jumlah mahasiswa yang paham konsep bertambah sebesar $73,15 \%$.

Penggunaan paradigma gaya gesek sebagai gaya reaksi juga dapat mempermudah mahasiswa dalam benentukan besarnya gesekan yang dialami benda khusunya pada benda yang sedang diam dan bergerak dengan kecepatan konstan. Dengan menggunakan paradigma ini, mahasiswa hanya perlu mengerahui seberapa besar gaya aksi yang diberikan benda terhadap lantai karena besarnya gaya gesek (gaya reaksi) sama dengan besar gaya aksi tersebut sesuai dengan hukum III Newton $\left(\mathrm{F}_{\mathrm{Aksi}}=\mathrm{F}_{\text {Reaksi }}\right)$. Oleh karena itu, sebanyak $90,12 \%$ mahasiswa menjadi paham konsep setelah diajarkan dengan menggunakan paradigma gaya gesek sebagai gaya reaksi ini atau mengalami peningkatan sebesar $82,71 \%$ yang diikuti oleh penurunan jumlah mahasiswa yang mengalami miskonsepsi yaitu sebesar $30,87 \%$.

Hasil temuan dan pembahasan di atas memperlihatkan bahwa penggunaan paradigma gaya gesek sebagai gaya reaksi dapat digunakan sebagai alternatif pembelajaran untuk meningkatkan pemahaman dan mereduksi miskonsepsi yang terjadi pada mahasiswa khusunya pada materi gaya gesek. Hasil penelitian ini sejalan dengan hasil penelitian Rokhmat, (2014) sebelumnya yang memperlihatkan bahwa penggunaan paradigma gaya gesek sebagai gaya reaksi dapat meningkatkan pemahaman konsep mahasiswa khususnya pada materi gaya gesek.

\section{KESIMPULAN}

Dapat disimpulkan bahwa penggunaan paradigma gaya gesek sebagai gaya reaksi secara umum dapat meningkatkan pemahaman konsep dan mereduksi miskonsepi mahasiswa khususnya pada materi gaya gesek. Dengan demikian, penggunaan paradigma gaya gesek sebagai gaya reaksi dapat digunakan sebagai alternatif pembelajaran di sekolah.

Dalam penelitian ini, peneliti hanya menggunakan satu kelas tanpa menggunakan kelas pembanding. Oleh karena itu, disarankan untuk penelitian selanjutnya menggunakan kelas pembanding untuk mengetahui perbandingan efektivitas antara metode, strategi, pendekatan, atau model pembelajaran yang satu dengan yang lainnya.

\section{UCAPAN TERIMA KASIH}

Tim peneliti sangat berterima kasih kepada Universitas Mataram yang sudah mendanai penelitian ini melalui hibah PNBP $2021 / 2022$

\section{REFERENSI}

Arslan, H. O., Cigdemoglu, C., \& Moseley, C. (2012). A Three-Tier Diagnostic Test to Assess Pre-Service Teachers' Misconceptions about Global Warming, Greenhouse Effect, Ozone Layer Depletion, and Acid Rain. International Journal of Science Education, 34 (11), 1667-1686. DOI: 10.1080/09500693. $\underline{2012.680618}$

Barke, H.D., Al Hazari, \& Yitbarek, S. (2009). Misconceptions in Chemistry. Addressing Perceptions in chemical Education. Berlin: Springer.

Frankel, J. R., Wallen, N. E. Hyun \& Hellen, H. (2012). How to Design and Evaluate Research in Education. New York: McGraw-Hill. 
Fratiwi, N. J., Kaniawati, I., Suhendi, E., Suyana, I. \& Samsudin, A. (2017). The transformation of two-tier test into four tier test on Newton's laws concepts. AIP Conference Proceedings, 1848, 050011. https://aip.scitation.org/doi/pdf/10.1063/1. 4983967

Hikmawati \& Sutrio (2019). Miskonsepsi dalam Fisika. Selong: Garuda Ilmu.

Ismail, I. I., Samsudin, A., Suhendi, E., \& Kaniawati, I. (2015). Diagnostik Miskonsepsi Melalui Listrik Dinamis Four Tier Test. Prosiding Simposium Nasional Inovasi dan Pembelajaran Sains (SNIPS 2015), Bandung-Indonesia. 381-384. https://www.researchgate.net/publication/ 301523361_Diagnostik_Miskonsepsi_Mel alui_Listrik_Dinamis_Four_Tier_Test

Kaniawati, I. (2017). Pengaruh Simulasi Komputer Terhadap Peningkatan Penguasaan Konsep Impuls-Momentum Siswa SMA. Jurnal Pembelajaran Sains, 1,(1), 24-26. http://journal2.um.ac.id /index.php/jpsi/article/view/637

Kaniawati, I., Fratiwi, N.J., Danawan, A., Suyana, I., Samsudin, \& Suhendi, E. (2019). Analyzing Students' Misconceptions about Newton's Laws through Four-Tier Newtonian Test (FTNT). Journal of Turkish Science Education, 16 (1), 110-122. https://files.eric.ed.gov/fulltext/EJ126503 9.pdf

Lestari, P.A.S., Rahayu, S., \& Hikmawati (2015). Profil Miskonsepsi Siswa Kelas X SMKN 4 Mataram pada Materi Pokok Suhu, Kalor, dan Perpindahan Kalor. Jurnal Pendidikan Fisika dan Teknologi, 1 (3), 146-153.

https://jurnalfkip.unram.ac.id/index.php/J PFT/article/view/251

Lestari, P.A.S., Rahayu, S., \& Hikmawati (2015). Profil Miskonsepsi Siswa Kelas X SMKN 4 Mataram pada Materi Pokok Suhu, Kalor, dan Perpindahan Kalor. Jurnal Pendidikan Fisika dan Teknologi, 1 (3), 146-153. Retrieved from: https://jurnalfkip.unram.ac.id/index.php/J PFT/article/view/251
McLaughlin, C. A. \& MacFadden B. J. (2014). At the Elbows of Scientists: Shaping science teachers' conceptions and enactment of 1nquiry-based 1nstruction. Research in Science Education, 44(6), 927-947. https://repository.si.edu/bitstream/handle/ 10088/22715/stri_RISE_article.pdf?seque nce $=1 \&$ isAllowed $=y$

Osman, E., BouJaoude, S. \& Hamdan, H. (2017). An investigation of lebanese G7-12 students' misconceptions and difficulties in genetics and their genetics literacy. International Journal of Science and Mathematics Education, 15(7), 12571280. https://eric.ed.gov/?id=EJ1154243

Rokhmat, J., (2014). Penggunaan Paradigma Gaya-Reaksi dan Pendekatan Analogi untuk Meningkatkan Pemahaman Konsep Gaya Gesek Bagi Mahasiswa Calon Guru Fisika (Studi Kasus Perkuliahan Fisika Dasar I). Pijar MIPA, 9 (2), 56-61. http://jurnalfkip.unram.ac.id/index.php/JP $\underline{\mathrm{M} / \text { article/view/45 }}$

Samsudin, A., Suhandi, A., Rusdiana D., Kaniawati I. \& Costu B. (2016). Investigating the Effectiveness of an Active Learning Based-Interactive Conceptual Instruction (ALBICI) on Electric Field Concept. In Asia-Pacific Forum on Science Learning and Teaching, 17(1), $1-41$. https://www.eduhk.hk/apfslt/download/v1 7_issue1_files/samsudin.pdf

Solas, E. C. \& Wilson, K. (2017). Instructor's use of student-generated annotated concept sketches in formative assessment in general science. Journal of Turkish Science Education, 14(4), 144-161. https://www.tused.org/index.php/tused/art icle/view/179/135

Sugiyono, (2012), Statistika Untuk Penelitian. Bandung: Alfabeta.

Suparno, Paul. (2005). Miskonsepsi dan Perubahan Konsep dalam Pendidikan Fisika. Jakarta: Grasindo.

Wahyuni, A.S.A., Rusdiana, D., Rustaman, N., \& Muslim (2018). Paper Conceptions and Misconceptions of PreService Teacher 
Ahmad Busyairi et al. (2021). Jurnal Ilmiah Profesi Pendidikan, 6 (1): 66 - 73

DOI: https://doi.org/10.29303/jipp.v6i1.154

about Light. International Conference on Advanced Multidisciplinary Research (ICAMR). 227 (1), hal. 56-60. Retrieved https://www.atlantis-press.com/ proceedings/icamr-18/55916854 